\title{
Segmental lichen aureus subsequent to interdigital tinea pedis: A rare clinical appearance of "id"-reaction?
}

\author{
Tatsuhiko Mori, Toshiyuki Yamamoto
}

Department of Dermatology, Fukushima Medical University, Fukushima, Japan

Corresponding author: Dr. Tatsuhiko Mori, E-mail: mtatsu@fmu.ac.jp

Sir,

A 59-year-old male visited our department, complaining of red itchy papules on his right lower leg. Initially, the papules appeared on the dorsum of his right foot, and spread upwards to the shin. He had no infectious symptoms, such as throat pain and fever, prior to the development of the dermatosis. Physical examination revealed that a number of reddish papules and erythematous lesions with slight scales were distributed along Blaschko's lines (Fig. la and b). Moreover, there were scaly erythema and vesicles between the third and fourth toes (Fig. lc), and a potassium hydroxide preparation test detected a number of fungi (Fig. 1d). Unfortunately, a mycological culture was not carried out. He had not been aware of his tinea pedis. A biopsy specimen taken from the dorsum of the foot showed parakeratosis, individual cell keratinization, spongiosis, and liquefaction degeneration in the epidermis. Furthermore, red blood cell extravasation, hemosiderin deposition, and perivascular inflammatory cell infiltrates, mainly composed of lymphocytes, were observed in the upper dermis (Fig. le). Immunohistochemistry revealed a number of CD4- as well as CD8-positive T-cells in the dermis, with a slight predominance of CD8positive epidermal T-cells (Fig. lf). Other dermatitis showing linear distribution, such as inflammatory linear verrucous epidermal nevus, linear lichen striatus, and linear lichen planus were all ruled out. The patient was successfully treated with topical corticosteroid (betamethasone butyrate propionate) ointment.

Lichen aureus is a rare variant of pigmented purpura frequently involving the lower legs. Lichen aureus rarely develops in a linear, segmental, or zosteriform

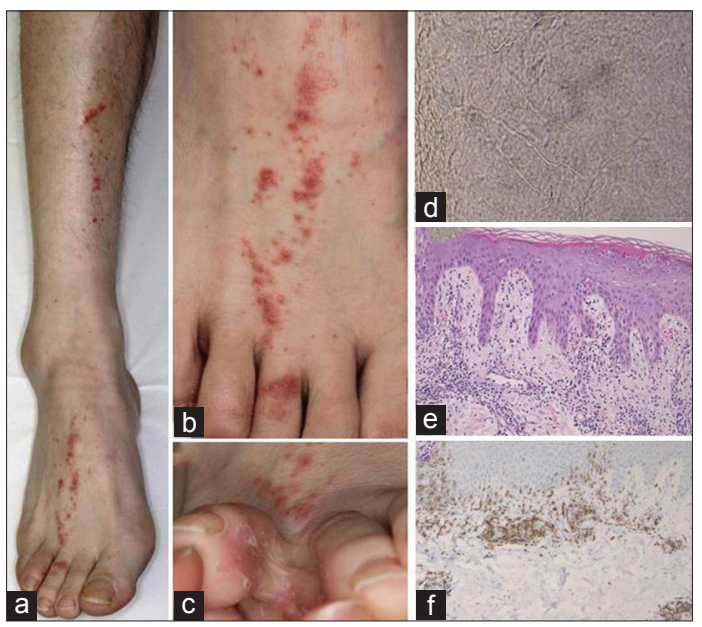

Figure 1: Clinical appearances showing linear distribution of reddish papular and erythematous lesions on the right lower leg $(a, b)$. Note the toe web scaly erythematous lesions (c). $\mathrm{KOH}$ test showed fungi (d). Histological features showing parakeratosis, slight acanthosis, individual cell keratinization, and liquefaction degeneration of the basal cell layer of the epidermis, with inflammatory infiltrates in the upper dermis (e). (hematoxylin-eosin, original magnification '200). Mononuclear cells also infiltrated in the upper dermis as well as the epidermis, which were immunoreactive for CD8 (f).

distribution following Blaschko's lines [1,2]. Although the etiology of lichen aureus is still unknown, possible candidates are increased venous pressure or stasis, increased capillary fragility, infection, drugs, and dysregulated T-cell-related immune reaction [2]. Also a few reports have suggested that an association with trauma and perforator vein incompetence may cause lichen aureus [3,4]. The Koebner phenomenon was demonstrated in a previously reported case [5]. Our patient developed lichen aureus following a tinea pedis infection in the intertriginous areas of the foot, from where reddish papules spread upward. Thus, fungal infection may have triggered the onset of

\footnotetext{
How to cite this article: Mori T, Yamamoto T. Segmental lichen aureus subsequent to interdigital tinea pedis: A rare clinical appearance of "id"-reaction? Our Dermatol Online. 2017;8(1):106-107.

Submission: 27.03.2016; Acceptance: 01.10.2016

DOI:10.7241/ourd.20171.30
} 
lichen aureus, although there was no evidence which showed the direct relationship between the lesion and tinea infection in our patient. In our case, a number of CD4- and CD8-positive T-cells infiltrated into the lesional skin, suggesting a cell-mediated cytotoxic injury. Following some external triggers such as tinea infection, adaptive effector T-cells may play an important role in the pathogenesis of lichen aureus. Lichen aureus has been shown to be resistant to topical therapy, and thus phototherapy, pentoxifylline, prostacyclin, and pulsed-dye laser have been used. In the present case, the lesions were transient and responded well to the topical corticosteroids. This may suggest that lichen aureus was triggered by fungal infection and thus ran an acute course. To the best of our knowledge, this is the first case of lichen aureus possibly induced by tinea pedis.

Hyperergic id-reaction secondary to fungi is known as mycid. Various clinical features are induced from distant focus of microbial infection, such as grouped or scattered follicular papules, dyshidrotic eczemalike lesions, or erythema multiforme-like erutions [6]. Histology shows perivascular inflammatory infiltrates in the dermis. In the present case, the eruptions originated from the root of the digit close to the inter-toe-web tinea pedis, spreading upwards, but no eruptions on the distant areas. Histological examination revealed prominent red blood cell extravasation and hemosiderin deposition, suggesting attack to the basement membrane by T-cells. Although the good response to the topical steroids may suggest an idreaction, we conclude that this is a rare case of lichen aureus subsequent to tinea pedis.

\section{REFERENCES}

1. Lee HW, Lee DK, Chang SE, Lee MW, Choi JH, Moon KC, et al. Segmental lichen aureus: combination therapy with pentoxifylline and prostacyclin. J Eur Acad Dermatol Venereol. 2006;20:1378-80.

2. Moche J, Glassman S, Modi D, Grayson W. Segmental lichen aureus: a report of two cases treated with methylprednisolone aceponate. Australas J Dermatol. 2011;52:e15-e18.

3. Ruiz-Esmenjaud J, Dahl MV. Segmental lichen aureus: onset associated with trauma and puberty. Arch Dermatol. 1988;124:1572-4.

4. Shelley WB, Swaminathan R, Shelley ED. Lichen aureus: a hemosiderin tattoo associated with perforator vein incompetence. J Am Acad Dermatol. 1984;11:260-4.

5. Reinhardt L, Wilkin JK, Trausend R. Vascular abnormalities in lichen aureus. J Am Acad Dermatol. 1983;8:417-20.

6. Thomas PA, Korting HC. The "id"-concept: new insight into an old problem. Eur J Dermatol. 1995;5:114-6.

Copyright by Tatsuhiko Mori, et al. This is an open access article distributed under the terms of the Creative Commons Attribution License, which permits unrestricted use, distribution, and reproduction in any medium, provided the original author and source are credited.

Source of Support: Nil, Conflict of Interest: None declared. 